Research Article

\title{
Recent changes to conservation of New Zealand's native biodiversity
}

\author{
Mairi Jay \\ Department of Geography, Tourism and Environmental Planning, University of \\ Waikato, Private Bag 3105, Hamilton, New Zealand
}

\begin{abstract}
This article examines recent changes to conservation in New Zealand. The argument is influenced by practical experience over the past 15 years, first as conservation planner employed by the Department of Conservation, then as an environmentalist involved in community conservation projects. The development of public-private partnerships in conservation action over the past 15 years is reviewed. These changes point to the configuration of new landscapes, although the diverse and uncoordinated nature of many contemporary initiatives suggest that future biological communities will comprise a diversity of hybrid mixes from predominantly native to fully non-native species.
\end{abstract}

Key words: biodiversity, conservation, New Zealand.

In 1987 the Department of Conservation was established to administer 30 per cent of New Zealand's land area for conservation purposes. By bringing all public conservation lands under one administrative umbrella with a clear mandate for conservation it was hoped the decline of New Zealand's native plants and animals would be reversed. Evidence of the next few years suggested that conservation efforts of the time were not enough to stem the decline. In 1997, the Ministry for the Environment published a national 'State of the Environment' report which stated that 'Biodiversity decline is New Zealand's most pervasive environmental issue, with 85 per cent of lowland forests and wetlands now gone, and at least 800 species and 200 subspecies of animals, fungi and plants considered threatened' (Taylor et al. 1997).

The Director-General of the Department of Conservation admitted in 1998 that, despite advances in the effectiveness of the Department, 'it is clear that current conservation efforts are insufficient to stem the decline in the health of indigenous biodiversity on the publicly conserved estate.' (Department of Conservation (DoC) 1998: 21). Two years later, the government published a national biodiversity strategy (DoC/Ministry for the Environment (MfE) 2000), which included as one of its strategic objectives, to 'halt the decline in New Zealand's indigenous biodiversity'.

The national biodiversity strategy indicated that in order to maintain and restore a full range of healthy, functioning natural ecosystems, it would be necessary to gain support from communities and private property owners and build partnerships with Māori iwi (tribal groups) and hap $\bar{u}$ (clans). As shown in Figure 1, most public conservation land is over $250 \mathrm{~m}$ above sea level, with sparse representation of lowland, coastal and wetland ecosystems. The involvement of private landowners is necessary to

Note about the author: Dr Mairi Jay is Senior Lecturer at the University of Waikato where she teaches environmental planning. Her main research interest is conservation planning.

E-mail: mairij@waikato.ac.nz 


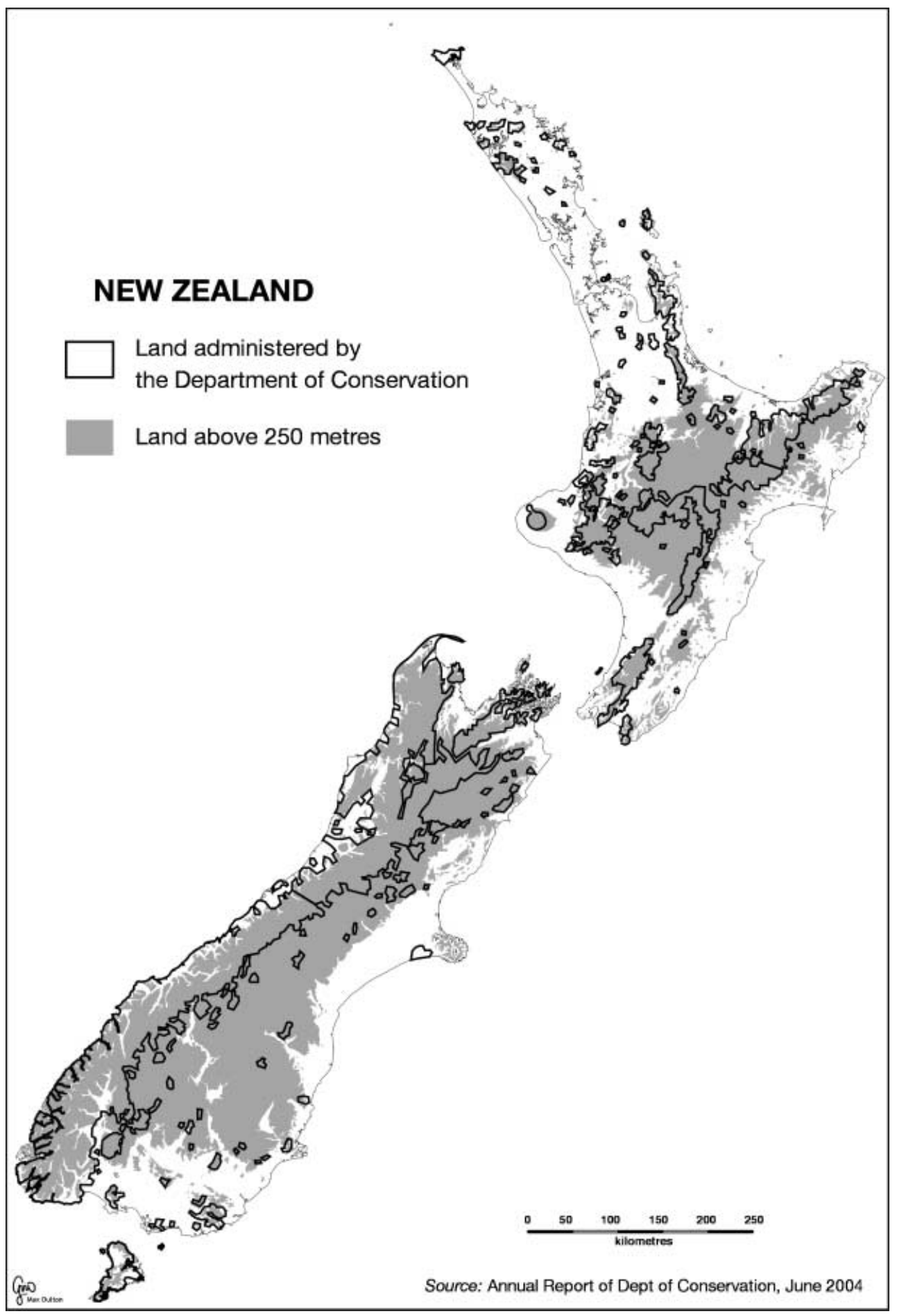

Figure 1 The location of public conservation land relative to the $250 \mathrm{~m}$ contour above sea level. 
ensure protection of a full range of the native ecosystems and species characteristic of New Zealand.

The report by the Director-General of Conservation and the New Zealand Biodiversity Strategy were both pessimistic about the prospects for maintaining New Zealand's native biodiversity in the face of environmental change, but expressed an openness to new ways of working in partnership with privatesector interest groups, communities and Māori. Both reports made reference to the importance of working with $i w i$, private landowners and 'stakeholders' (individuals and groups with an interest in conservation). In many ways they can be seen as signalling a new era in New Zealand conservation, involving a growing awareness of the uniqueness and value of the country's native fauna and flora. The following sections explore the emergence of public/private partnerships in conservation and natural resource management since the early 1990s. The treatment is short for reasons of space and because published information is not readily available.

\section{Recent New Zealand environmental activism}

Throughout the first half of the 20th century the most significant New Zealand environmental legislation was pragmatic and ad hoc, responding to specific problems as they arose. The underlying philosophy was utilitarian, with the environment viewed mainly as a resource for human use. Environmental controls aimed at limiting or counteracting externalities caused by exploitation of resources. For example, the Soil Conservation \& Rivers Control Act 1941 was a reaction to the devastation of soil erosion brought about by the destruction of native forest on hill country farms over previous decades; the Water \& Soil Conservation Act 1967 was largely a response to problems created by uncontrolled taking and discharging of water, and the Clean Air Act 1972 was a response to the problems of air pollution. Māori perspectives were absent from this legislation.
The 1960s, 1970s and 1980s saw a growing international concern about the environment, as mirrored by such events as the 1972 United Nations Conference on the Human Environment in Stockholm and the 1992 United Nations Conference on Environment and Development in Rio de Janeiro (Grubb et al. 1993). International concern was reflected nationally by growth in the number of New Zealanders concerned about the environmental damage occurring in New Zealand. The environmental movement began to enjoy significant political support. For example, the Values Party, established in 1972, articulated a philosophy that ran counter to the productivist ethic of the day, and it performed well in the elections of 1972 and 1975 (Buhrs \& Bartlett 1993).

Several high profile environmental conflicts also played an important part in raising public concern. For example, in 1969, when government proposed to raise the level of Lake Manapouri in the South Island for electricity generating purposes, a 'Save Manapouri' campaign was mounted and received such broad public support that, in 1972, the government retracted and agreed to maintain the Lake at its natural level (Wheen 2002). Other disputes also arose between environmentalists and the New Zealand Forest Service over harvesting of native forest (Memon and Wilson 1993), between recreationists and farmers over the use of water from recreationally and scenically significant rivers (e.g. the Motu and Rakaia), and between mining companies and local residents about the environmental impacts of mining.

The surge of environmental concern was reflected in new or revamped environmental legislation from the mid-1970s. These culminated in the Resource Management Act (1991), a statute that controls development of natural resources throughout the country. The purpose of the Act is to promote the sustainable management of natural and physical resources (excluding minerals), by managing their use, development, and protection while sustaining their potential to meet the foreseeable needs of future generations, safeguarding the life-supporting capacity of air, water, soil, and ecosystems, and 'avoiding, remedying, or mitigating any adverse effects of 
activities on the environment.' (RMA, Section 5). Section 6(c) of the Act requires that persons exercising functions and powers under the Act must recognize and provide for 'areas of significant indigenous vegetation and significant habitats of indigenous fauna'.

The implementation processes stipulated by the Resource Management Act 1991, give local authorities (District/City/Regional Councils) responsibility for instituting the principles and policies outlined above. Despite conflict over terms such as 'significant' (what is 'significant' indigenous vegetation?) there is little question that the operation of the Act has prompted decision-makers to view environmental issues with more attention and critical consideration. Prospective resource users are routinely expected to 'avoid, remedy or mitigate' the adverse environmental effects of their developments. The principles imposed by the act are to an extent the impetus behind a number of public/ private partnerships described further on.

\section{Public-private partnerships for conservation}

The changes in environmental management wrought by the Resource Management Act 1991 have been significant, but no less so has been a growth in voluntary conservation by individuals, organizations and community groups. February 2, 2005 was National Wetlands Day, a day that marked the signing of the international RAMSAR Convention in 1971 for the conservation of wetlands. ${ }^{1}$ A programme of activities took place throughout New Zealand. In Waikato this involved a tour of its wetlands. The tour was sponsored by a consortium comprising energy company, Mighty River Power, state-owned Solid Energy (formerly Coal Corp), the Department of Conservation, the New Zealand Fish and Game Council, and the National Wetlands Trust. It involved some 150-200 interested citizens, Māori and Pākehā, who travelled by bus to view a series of restoration projects undertaken by Solid Energy and a private landowner.

The projects included a wetland created with waste minewater by Solid Energy and a recreational lake formed from the open cast mine of Weavers Crossing for the community of Huntly. Another project involved a dairy farmer who had removed the introduced willows from his lake to allow native sedge and cabbage trees to grow, and had conserved habitat for eel populations to control pest fish. Discussion included management issues such as weeds and pest control, and innovative methods of addressing them. A comment by the farmer was: 'We are helping one another and learning as we go.' Not only was this true of the farmer. Such consortia of public, private, nongovernmental organization (NGO) and commercial sector interests are relatively recent phenomena. Public and private institutions, individuals and communities are also 'learning as they go' through new ways of working together and finding solutions to conservation concerns that speak widely to the New Zealand public.

The seeds of public and private partnerships in conservation were sown at the formation of the Department of Conservation. Formed from the amalgamation of three former government organizations, the new Department was responsible for administering nearly eight million hectares of land, the conservation of marine mammals, and areas of marine protection. It was expected to undertake a wide range of management responsibilities, from rural fire control and mountain rescue, to weed and pest control, threatened species survival, historic resources protection, and provision for recreation and tourism.

Within a very short time the Department found that it did not have sufficient resources to do the work expected of it. The very extent of the conservation estate as well as the range and complexity of responsibilities were prime reasons. But the new Department had support from many in the wider community, including members of the New Zealand Conservation Authority and the Regional Conservation Boards. The Conservation Authority and its Conservation Boards were formed by the Minister of Conservation to give advice on conservation matters. Membership is for a fixed term, and members are deliberately selected from a range of community interests including Māori tribal groups, environmental groups, and 
tourism interests. Many of the representatives on the Authority and Conservation Boards knew business models of management and were open to new ways of enlisting conservation resources. ${ }^{2}$ They were soon instrumental in helping to raise wide public awareness of the scale of the conservation task and the recognition that the work of conservation could not be left to the Department alone.

By 1990 the Threatened Species Trust (TST) had been established as a partnership between the Department of Conservation, Royal Forest and Bird Protection Society and the New Zealand Conservation Authority to 'attract financial sponsorship to support recovery programmes, habitat management and research directed towards New Zealand's threatened native plants and animals' (TST 2005). That same year, it achieved sponsorship for the Kakapo Recovery Programme ${ }^{3}$ by Comalco aluminium smelting company (Comalco 2005). Further sponsorships included the Bank of New Zealand Kiwi Recovery Trust (comprising of the Bank of New Zealand, the Department of Conservation and the Royal Forest and Bird Protection Society), Project Crimson Trust (a partnership with Carter, Holt, Harvey to secure protection for the pohutukawa), and the Takahe Recovery Programme involving the Department of Conservation and the Flight Centre.

Apart from the groups formed in association with the Department of Conservation or Threatened Species Trust, other major private environmental groups evolved. They included the Karori Wildlife Sanctuary in Wellington, the Native Forest Restoration Trust, which purchased areas of native forest for protection and presently owns some 6000 ha (NFRT 2005), the Travis Wetland Trust in Christchurch, the National Wetland Trust at Rangiriri (between Auckland and Hamilton), and the Miranda Wetlands Trust of the Firth of Thames. Groups of rural landowners, urban environmentalists, and small town residents interested in conservation of native species emerged all around the country. New Zealand Landcare Trust (NZLT 2005) lists 187 landcare groups on its web site and the New Zealand Ecological Restoration Network notes 929 groups. $^{4}$
At an individual level, a growing number of private landowners have started to appreciate the value of native forest and wetland on their property. This realization shows in the number of private landowners who have covenanted land under the Queen Elizabeth II Trust (QEII 2004) since its inception in the late 1970s (2393 open space covenants protecting over 85000 hectares).

Some of the public/private initiatives have involved significant efforts and funding. For example, the Maungatautari Ecological Island Trust in Waikato, at the time of writing this article, have raised $\$ 7.5$ million towards the cost of a predator-free fence around the mountain (an area of some $3400 \mathrm{ha}$ ) and they expect to raise the same amount again to complete fencing and pest eradication. The Supporters of Tiritiri Matangi have co-ordinated the restoration planting of Tiritiri Matangi, a 220-ha island in the Hauraki Gulf. Between 1984 and 1994 the Supporters co-ordinated the planting of 250 000-300 000 trees by volunteers. In 2003 the newly formed Motu Kaikoura Trust successfully secured $\$ 10.5$ million from the government, the Auckland Savings Bank Charitable Trust, and the local and regional governments to purchase the 564 ha Kaikoura Island in the middle of Hauraki Gulf.

A number of public/private partnerships involving major resource users and developers have been spawned by the requirements of the Resource Management Act 1991 for resource users to 'avoid, remedy or mitigate' any detrimental environmental effects of their activities. For example, Mighty River Power established the Waikato Catchment Ecological Enhancement Trust to administer an annual fund for environmental actions which mitigate the environmental effects of its resource consents for electricity generation on the Waikato River. A similar arrangement has applied to Genesis Energy to offset its use of the Waikato River for the discharge of heated wastewater.

In short, the National Wetlands Day sojourn in Waikato illustrated many of the changes that have taken place in New Zealand conservation during the past few years. It demonstrated the environmental mitigation measures 
(a constructed wetland and lake) undertaken by a resource user in response to principles of the Resource Management Act 1991; the initiative of a private landowner who has come to view the lake on his land as an asset rather than a production liability; the cooperation of public and private interests encompassed the expert advice given by Department of Conservation officers to Solid Energy and the farmer; and the initiative of Mighty River Power (private sector); and non-governmental Fish and Game Council and the National Wetlands Trust in organizing and sponsoring the event. Finally, there were the members of the public who turned up because they wanted to know more. The event revealed co-operation between groups that seldom got together in the past, and willingness by all those involved to look beyond the boundary lines of public/private property and ethnic difference for the sake of environmental protection and restoration.

Equally, the event revealed some of the weaknesses inherent in conservation by public/private partnerships. Public-private initiatives are largely driven by social and economic concerns and capacities of the people involved, rather than ecological or conservation qualities. They are subject to the ebb and flow of community leadership and membership; to lack of expert knowledge or critical resources; to inadequate or inconsistent planning and project management; and to issues of legal, financial and bureaucratic responsibility such as health and safety concerns, legal status and financial status (Wilson 2005). The types of projects selected are also influenced by social, demographic and economic factors. Thus an area may be selected for historic, aes- thetic or symbolic reasons (such as a picnic site or beautiful view, for example), while areas of ecological importance such as nesting or spawning habitat for endangered birds or fish are passed by. Areas close to the larger cities are likely to receive more attention than remote areas simply because there are more people available to offer volunteer assistance. Areas within wealthier regions such Waikato, Auckland or Wellington may be more likely to attract sponsorship funding than poorer regions such as Northland or the East Coast of the North Island.

Initiatives such as the Kakapo and Kiwi recovery programmes have been criticised for applying mainly to 'charismatic megafauna' such as kiwi, kakapo, and takahe without necessarily improving the conservation of other equally threatened but less humanly interesting species such as the tuatara, insects, or the Powliphanta snails. The counter argument is that they mobilize resources that would not otherwise be available, and enable 'vote conservation' to be extended to less charismatic species as well as conservation efforts that are less glamorous but equally important. There may be some truth to both arguments.

Equally possible, the public/private partnerships have allowed the Department to shift resources from species and ecosystem protection to other functions that would not otherwise have received funding. The figures in Table 1 show a $35 \%$ increase in expenditure by the Department during the past 5 years, but suggest that the relative proportion of the Department's expenditure on conservation management has fallen from $53 \%$ of the total in 1999 to $47 \%$ in 2004 . This reduction is

Table 1 Output class expenditures of the Department of Conservation, 1999-2004

\begin{tabular}{|c|c|c|c|c|c|}
\hline \multirow[b]{2}{*}{ Vote 'Conservation' Output Classes } & \multicolumn{2}{|c|}{1999} & \multicolumn{2}{|c|}{2004} & \multirow{2}{*}{$\frac{1999-2004}{\% \text { change }}$} \\
\hline & $\$ 000 \mathrm{~s}$ & $\%$ of Total & $\$ 000 \mathrm{~s}$ & $\%$ of Total & \\
\hline Natural and Historic Heritage Management & 92729 & 53 & 125516 & 47 & 35 \\
\hline Recreation Management & 47498 & 27 & 106667 & 40 & 98 \\
\hline Conservation with the community & 29891 & 17 & 30325 & 11 & 1 \\
\hline Policy advice and service & 5652 & 3 & 6215 & 2 & 10 \\
\hline Total expenditure & 175770 & 100 & 268723 & 100 & 53 \\
\hline
\end{tabular}

Source: Adapted from the Department of Conservation Annual Reports for 1999/2000 and 2003/04.

C The New Zealand Geographical Society 2005 
significant given that the conservation estate expanded during that time with the addition of several marine reserves and South Island high country land (from the review and reapportioning of publicly owned but formerly leased pastoral holdings). However, the main increases appear to be related to provision of recreational opportunities rather than a shift to partnership with communities. The shift in recreational opportunities is consistent with the importance that conservation land holds for New Zealand's tourism industry.

\section{Conclusion: Progress toward a transformed New Zealand nature?}

Clear empirical evidence for a significant change in New Zealand's conservation is difficult to obtain, but personal observation and experience suggests a sea change in the manner and direction of conservation in this country. The change is from a view of conservation as the responsibility of government on behalf of the people, to a view of conservation as a society-wide responsibility. Private sector interests such as Mighty River Power and Solid Energy, undertake environmental repair in part because their resource consents under the Resource Management Act 1991 require them to, but also for good community and public relations. Corporate sponsors and charitable trusts such as ASB (Auckland Savings Bank) Trusts, Bank of New Zealand and Comalco provide funds because they perceive that there is popular public support for doing so.

The long-term environmental consequences of the increase in public/private partnerships in New Zealand are not yet clear. The nature and success of many projects by public/private partnerships are determined by social, legal or economic factors rather than criteria of ecological value. It may be that in many cases, their prime conservation value is an educational one; that they nurture emotional ties of commitment to New Zealand's native heritage and a greater understanding of ecological processes.

The ecological consequences of European settlement and economic consolidation continue to ripple as possums, goats, stoats, wasps, and other ecologically destructive organisms make their way to the furtherest corners of New Zealand. In addition, New Zealand's participation in global trade and travel bring ongoing threats of ecological invasion and species reshuffling. But the new public/private partnerships, spurred on by legislative pragmatism no less than sentiment, are signs that New Zealand's human residents appreciate what is unique about their landscape and its native species, even as they learn what is needed to protect them.

The new conservation approaches coincide with changing cultural attitudes that value native species and landscapes as a source of identity and spiritual significance. In the past native landscapes and species were mostly confined to remote situations, but recent decades have seen people protecting native species in their own communities and domestic gardens. In doing so, they are applying Māori ideals of kaitiakitanga (stewardship) close to home, and helping to create mixed landscapes of native and introduced species that will one day function as components of hybrid ecosystems. We are witnessing a transfiguration of the landscapes from Crosbie's 'neo-Europe' (Crosby 1986) of postsettlement New Zealand to ones that will include all shades and proportions of native and exotic species throughout towns, cities, the farmed countryside, and remote corners of the land.

\section{Endnotes}

1 RAMSAR is the name of the city in Iran where an intergovernmental treaty was signed in 1971 for national action and international cooperation for the conservation and wise use of wetlands (http://www.ramsar.orgl, accessed July 1, 2005)

2 For example, see the description of members in the Department of Conservation's publication Green Print, The Department, The Estate, The Issues, The State of Conservation in New Zealand in 1990: A Brief to the Incoming Administration (DoC 1990) and A Guide to the Department of Conservation: A Briefing for the New Minister of Conservation, Volume Two, August 2002.

3 The kakapo (Strigops habroptilus) is a large, nocturnal, critically endangered native parrot.

4 While the New Zealand Ecological Restoration Network notes that there are some difficulties in keeping their site listing up to date, and groups 
may spring up and die away all the time, the list does indicate that large numbers of people have been involved in voluntary environmental activity at one time or another.

\section{References}

Buhrs T, Bartlett RV (1993). Environmental Policy in New Zealand. Oxford University Press, Auckland.

Comalco (2005). Kakapo recovery programme. Accessed at: http://www.kakaporecovery.org.nz/ people.comalco.html (cited 27 April 2005).

Crosby AW (1986). Ecological Imperialism: The Biological Expansion of Europe, 900-1900. Cambridge University Press, New York.

Department of Conservation (1990). Green Print, The Department, The Estate, The Issues, The State of Conservation in New Zealand in 1990: A Brief to the Incoming Administration. Department of Conservation, Wellington.

Department of Conservation (1998). Restoring the Dawn Chorus: Department of Conservation Strategic Business Plan. Department of Conservation, Wellington.

Department of Conservation/Ministry for the Environment (2000). The New Zealand Biodiversity Strategy: Our Chance to Turn the Tide. Department of Conservation and Ministry for the Environment, Wellington.

Grubb M, Koch M, Munson A, Sullivan F, Thomson K (1993). The Earth Summit Agreements: A Guide and Assessment. Earthscan and the Royal Institute of International Affairs, London.
Memon PA, Wilson GA (1993). Indigenous forests. In: Memon PA, Perkins HC, eds Environmental Planning in New Zealand. The Dunmore Press, Palmerston North, pp. 97-119.

New Zealand Landcare Trust (2005). Landcare Virtual Communities. New Zealand Landcare Trust. Accessed at: http://www.landcare.org.nz/ action/groups_fs.htm (cited 9 February 2005).

New Zealand Native Forest Restoration Trust (2005). New Zealand Native Forest Restoration Trust Home Page. Accessed at: http://www.nznfrt.org.nz/ (cited 9 February 2005).

Queen Elizabeth the Second National Trust (QEII) (2004). Report of the Queen Elizabeth the Second National Trust for the Year Ended 30 June 2004. Queen Elizabeth the Second National Trust, Wellington.

Taylor R, Smith I, Cochrane P, Stephenson B, Gibbs N (1997). The State of New Zealand's Environment 1997. GP Publications for the Ministry for the Environment, Wellington.

Threatened Species Trust (2005). Threatened Species Trust Programme. Threatened Species Trust, Wellington. Accessed at: http://www.kakaporecovery.org.nz (cited 9 February 2005).

Wheen N (2002). A history of New Zealand environmental law. In: Pawson E, Brooking T, eds. Environmental Histories of New Zealand. Oxford University Press, Melbourne, pp. 261-74.

Wilson C (2005). Developing Effective Partnerships Between the Department of Conservation and Community Groups. Science for Conservation 248, Department of Conservation, Wellington. 